\title{
Comparison of the effect of heparin and citrate on platelet aggregation
}

\author{
J. R. O'BRIEN, S. M. SHOOBRIDGE, AND W. J. FINCH
}

From the Portsmouth and Isle of Wight Area Pathological Service

SYNOPSIS When whole blood was passed through a column of glass beads, heparinized and nativen blood gave similar results. With citrated blood far fewer platelets were lost on the column. Thus citrate inhibits this test and heparin has no effect.

Platelet-rich plasma (PRP) was prepared from citrated and heparinized blood and the responsesi in a number of aggregation tests were compared. With added adenosine diphosphate and adrenalineo (first wave), the response in heparin PRP was greater than that in citrate PRP and was proportionaL to the amount of free calcium ions. With added collagen and adrenaline (second wave) the response्छ was worse in heparin than in citrate platelet-rich plasma. It is concluded that heparin has no effece on the adhesive forces but inhibits the release mechanism. This may be of therapeutic importance

Clotting must usually be prevented before any platelet aggregation studies can be carried out. Citrate and heparin are often used. Spaet and Zucker (1964) found a more vigorous response in heparinized platelet-rich plasma. Skoza, Zucker, Jerushalmy, and Grant (1967) show that citrate decreases aggregation by removing calcium ions. When O'Brien (1968) studied the inhibitory effect of aspirin on the release mechanism, the results in heparin PRP were less clear cut than in citrate platelet-rich plasma. Accordingly, it seemed appropriate to compare the effect of these two anticoagulants in a number of situations and especially in those involving the release mechanism.

\section{METHODS}

For the glass bead column experiments the method of O'Brien and Heywood (1967) was used. Blood was collected into siliconed tubes containing saline or the appropriate concentration of anticoagulant, mixed, and then sucked into the plastic tube for attachment to the column of glass beads. A fast speed was used (transit time $3 \mathrm{sec}$ ). The order of testing these mixtures was varied and the experiments were always finished within 10 minutes.

The basic design for aggregation experiments consisted of collecting blood from a single donor into sample tubes containing heparin or citrate of varying concentrations. Platelet-rich plasma was prepared from each sample and the response of all the samples to a variety of aggregating agents was compared. The technique and Received for publication 19 June 1968. the methods of measuring the degree of aggregation have already been detailed (O'Brien, Heywood, and Heady, 1966). Essentially, PRP is stirred at $37^{\circ} \mathrm{C}$ and the aggregating agent added. Changes in light transmission are recorded graphically and the various maximab 'slopes' are measured. These indicate the rate oß̊ aggregation and hence the number of successful collisions $\vec{F}$ thus the slopes reflect the 'stickiness' of the plateles membrane. The number of platelets in each sample was counted and the results adjusted accordingly. Usually the counts in all samples were similar so no adjustment. was necessary.

The final concentrations of citrate were $0.32 \%$ and $0.64 \%$ and that of heparin was 3.6 units and 91 units per $\mathrm{ml}$ (Pularin, Evans Medical). The strength of the aggregating agents was chosen according to the plasma used, to give a moderate response (eg, a 'slope' of 60) in the $0.32 \%$ citrate sample. The slopes of the various samples were measured, and for comparison were expressed as a percentage of the response in $0.32 \%$ citrate. For each aggregating agent, four to eigh independent experiments were made and the results weres averaged. In almost all experiments there was closen agreement.

To study the possible inhibitory effect of excess heparin $\omega$ PRP was prepared, using heparin 3.6 units per $\mathrm{ml}$, and this was compared with the same PRP to which more hepario had been added to give a final concentration of 104 unit\$D per millilitre.

The aggregating agents and the range of final con-0 centrations were as follows: ADP (Sigma) $5 \mathrm{M} \times 10^{-\overline{5}}$ to $2.5 \mathrm{M} \times 10^{-6}$; serotonin (Sigma) $5 \mathrm{M} \times 10^{-6}$; adren aline hydrogen tartrate $5 \mathrm{M} \times 10^{-9}$ to $5 \mathrm{M} \times 10^{-4}(\mathrm{BDH}) \stackrel{\stackrel{?}{\mathrm{P}}}{\mathrm{C}}$ A suspension of collagen was prepared by grinding the dried material (Sigma) by hand in saline. Coarse 
particles were removed by centrifugation and the strength was adjusted by dilution to give a moderate response.

\section{RESULTS}

When citrated $(0.32 \%)$ blood was passed through the glass bead column very few platelets $(7 \%)$ were retained (Table I), so weaker citrate concentrations were also studied. In native blood $33 \%$ of the platelets were retained. The addition of heparin had no effect, but the addition of citrate even in weak concentration $(0.10 \%)$ prevented the retention of most of the platelets $(14 \%$ retained).

\section{TABLE I}

EFFECT OF CITRATE, HEPARIN, AND NO ANTICOAGULANT ON THE RETENTION OF PLATELETS IN A COLUMN OF GLASS BEADS

\begin{tabular}{lc}
$\begin{array}{l}\text { Final Concentration of } \\
\text { Anticoagulant }\end{array}$ & $\begin{array}{l}\text { Percentage of } \\
\text { Platelets } \text { Retained }\end{array}$ \\
\hline Citrate $0.32 \%$ & 7 \\
Citrate $0.21 \%$ & 11 \\
Citrate $0.10 \%$ & 14 \\
Native blood & 33 \\
Heparin $3 \cdot 6$ units per ml & 35
\end{tabular}

In the aggregation experiments (Table II) $0.64 \%$ citrate with ADP gave a very poor response. When the citrate was weaker $(0.32 \%)$ a better response occurred. In heparin PRP (3.6 units per $\mathrm{ml})$ the response was greater still. Increasing the concentration of heparin to 91 units per $\mathrm{ml}$ did not alter the results. The first wave of aggregation with adrenaline

\section{TABLE II}

EFFECT OF DIFFERENT CONCENTRATIONS OF CITRATE AND HEPARIN ON THE RESPONSE OF PLATELETS TO DIFFERENT AGGREGATING AGENTS

\begin{tabular}{|c|c|c|c|c|c|}
\hline \multirow{4}{*}{$\begin{array}{l}\text { Final } \\
\text { Concentration } \\
\text { of Anticoagulant }\end{array}$} & \multicolumn{5}{|c|}{ Aggregating Agent } \\
\hline & \multicolumn{5}{|c|}{$\begin{array}{l}\text { (Slope Expressed as a Percentage of that } \\
\text { Obtained with Citrate } 0.32 \% \text { ) }\end{array}$} \\
\hline & \multirow[t]{2}{*}{$A D P$} & \multicolumn{2}{|c|}{ Adrenaline } & \multirow[t]{2}{*}{ Collagen } & \multirow[t]{2}{*}{$5 H T$} \\
\hline & & $\begin{array}{l}\text { Ist } \\
\text { Slope }\end{array}$ & $\begin{array}{l}\text { 2nd } \\
\text { Slope }\end{array}$ & & \\
\hline $\begin{array}{l}\text { Citrate } 0.64 \% \\
\text { Citrate } 0.32 \% \\
\text { Heparin } 3.6 \text { units per } \mathrm{ml} \\
\text { Heparin } 91 \text { units per } \mathrm{ml}\end{array}$ & $\begin{array}{r}18 \\
100 \\
167 \\
176\end{array}$ & $\begin{array}{r}47 \\
100 \\
150 \\
160\end{array}$ & $\begin{array}{r}65 \\
100 \\
37 \\
61\end{array}$ & $\begin{array}{r}3 \\
100 \\
43 \\
29\end{array}$ & $\begin{array}{r}23 \\
100 \\
\frac{95}{25}\end{array}$ \\
\hline
\end{tabular}

was influenced by these various concentrations of both anticoagulants in a parallel manner. The second wave of aggregation with adrenaline (O'Brien, 1963) and the response to collagen gave a quite different pattern of results. Again $0.64 \%$ citrate gave a poor response and $0.32 \%$ a better response but the response in the presence of heparin was much

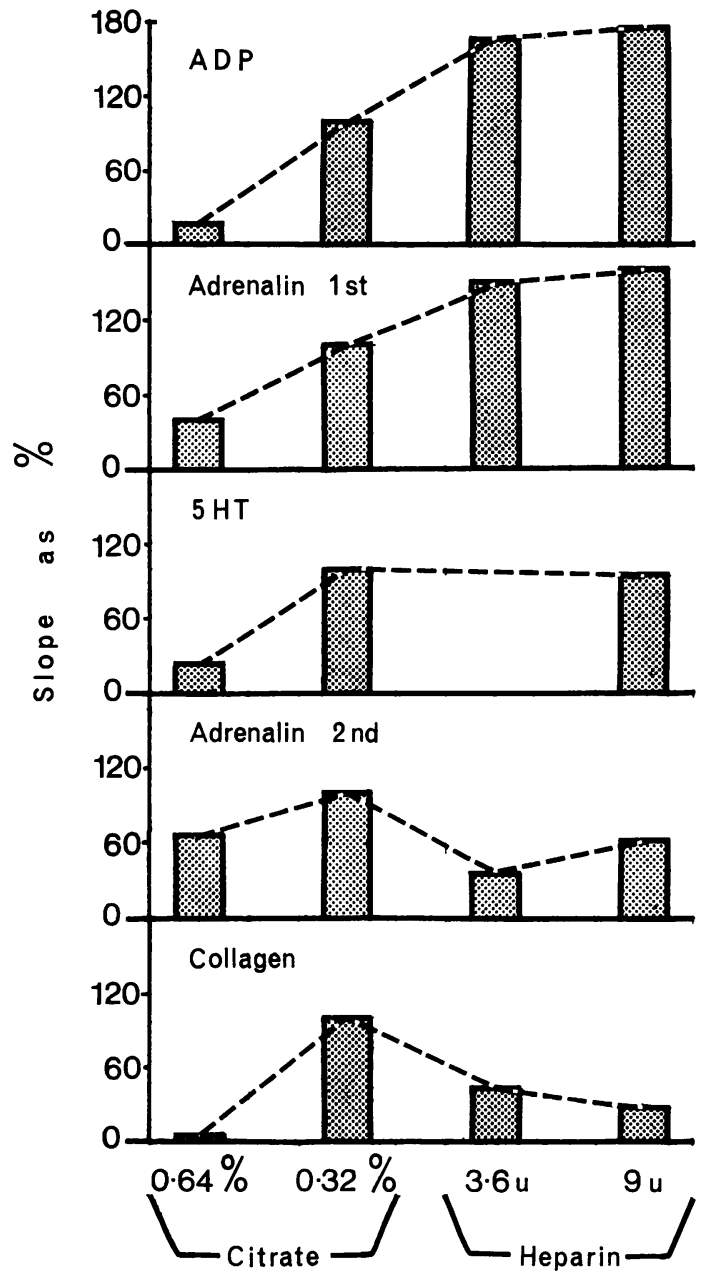

FIG. 1. Diagram of the results.

worse than that in citrate $0.32 \%$; the results in strong heparin may have differed from those in weaker heparin but were still far worse than those in the citrate platelet-rich plasma. The pattern of response to $5 \mathrm{HT}$ was intermediate; the result in heparin was similar to that in $0.32 \%$ citrate plateletrich plasma. These results are represented semigraphically in Figure 1. It will be seen that the position on the abscissa of citrate $0.32 \%$ has arbitrarily been put equidistant from $0.64 \%$ citrate and heparin 3.6 units per $\mathrm{ml}$. Thus the position of 3.6 units per $\mathrm{ml}$ heparin corresponds to the hypothetical position of $0.0 \%$ citrate.

The poor results in heparin PRP with collagen and adrenaline (second slope) might suggest that heparin had an inhibitory effect. Accordingly, 
heparin PRP (3.6 units per $\mathrm{ml}$ ) was prepared. To half of this PRP strong heparin was added (final concentration 104 units per $\mathrm{ml}$ ) and saline to the other half. These two subsamples were compared using all the aggregating agents (Table III). It will be seen that the further addition of heparin had no effect on aggregation induced by ADP, adrenaline first and second slopes, or $5 \mathrm{HT}$, but strong heparin markedly decreased the response to collagen.

\section{TABLE III}

EFFECT OF VARYING THE CONCENTRATION OF HEPARIN ON PLATELET AGGREGATION

\begin{tabular}{|c|c|c|c|c|c|}
\hline \multirow{3}{*}{$\begin{array}{l}\text { Final } \\
\text { Concentration } \\
\text { of Heparin } \\
\text { (units } / \mathrm{ml} \text { ) }\end{array}$} & \multicolumn{5}{|c|}{ Aggregating Agent } \\
\hline & \multirow[t]{2}{*}{$A D P$} & \multicolumn{2}{|c|}{ Adrenaline } & \multirow[t]{2}{*}{ Collagen } & \multirow[t]{2}{*}{$5 H T$} \\
\hline & & Ist Slope & 2nd Slope & & \\
\hline \multirow{2}{*}{104} & 143 & $\begin{array}{l}88 \\
98\end{array}$ & 41 & 71 & 97 \\
\hline & $\begin{array}{l}\text { Result } \\
\text { of the }\end{array}$ & $\begin{array}{l}104 \text { units } \\
\text { it with } 3.6\end{array}$ & $\begin{array}{l}40 \\
\text { nits per } \mathrm{ml}\end{array}$ & $\begin{array}{c}20 \\
\text { ssed as a p }\end{array}$ & ercentag \\
\hline 104 & $96 \%$ & $111 \%$ & $112 \%$ & $37 \%$ & $97 \%$ \\
\hline
\end{tabular}

\section{DISCUSSION}

In the glass bead column test, native blood and heparinized blood gave similar results; it is concluded that heparin has no inhibitory effect. The presence of even weak citrate results in very few platelets being retained so it may be concluded that this situation is very sensitive to the concentration of calcium ions.

In all the aggregation tests, increasing the concentration of citrate from $0.32 \%$ to $0.64 \%$ always resulted in a decreased response. These results are in line with those of Skoza et al (1967) and suggest that all these aggregation phenomena are calcium dependent. This suggestion gains strong support from Figure 1. It will be seen that with ADP and the adrenaline (first slope) the result using heparin PRP almost coincides with the hypothetical point where the citrate concentration is nil. Thus the apparent increase in response in heparin may be fully explained by the absence of citrate. There is no evidence that heparin itself enhances or inhibits these responses since the addition of strong heparin (Table III) or the collection of blood into strong heparin did not alter the result. Clayton and Cross (1963) and Rowsell, Glynn, Mustard, and Murphy (1967) also produced evidence that heparin itself has no inhibitory or enhancing effect on ADP-induced aggregation.

It is common knowledge that PRP prepared in heparin is more likely when handled to undergo spontaneous aggregation than citrate platelet-rich plasma. A possible interpretation was that heparin was a weak aggregating agent. However, no evidence to support this has been found, and thus this difference is presumably due to the relative inhibitor $\stackrel{0}{\frac{0}{5}}$ effect of citrate. Accordingly, although heparin PRP. is more difficult to work with, its instability probable represents more accurately the state of platelets in vivo.

Hovig (1963) reported that strong heparin addedp to citrated rabbit PRP decreased the response to 8 tendon extract. The present results are in agreement with this. Why are the collagen and adrenaline second slope results in heparinized PRP so much les? than in citrated PRP, when it has already been shown that in other situations citrate decreases the response by removing calcium and heparin has no inhibitor $\overline{\mathrm{B}}$ effect? It is now established that in both these situations, namely, collagen-induced aggregation and the adrenaline second wave, aggregation is induce $\vec{b}$ by the liberation of intrinsic ADP from platelets as result of the release mechanism (Grette, 1962). Thus heparin may have some inhibitory effect on the release mechanism. Increasing the concentration of the heparin further decreases the result with collage (Tables II and III) thus supporting the suggestion? that heparin inhibits release. Heparin could have $\vec{a}$ specific effect on collagen itself, but this seems les: probable because the adrenaline second slope if inhibited similarly and it depends entirely on release due to propinquity (O'Brien, and Woodhouse 1968). In vitro, heparin could not be added to citrate PRP without sometimes producing aggre gation. However, Rowsell et al (1967) showe\& that heparin given to dogs decreases the response $0 \overrightarrow{\vec{\Phi}}$ citrated PRP to collagen. They comment that there may be a more subtle interaction of platelets with the endothelium. It can now be suggested that the interaction was the effect of heparin on the releas reaction.

These findings in vitro, suggesting that heparie inhibits the release reaction, may be of more thas academic interest. Certainly most effects of heparin in vivo are related to its antithrombic and ito lipoprotein lipase-stimulating activity. The release phenomenon probably is of physiological importance and a recent study of the effect of aspirin (O'Brien 1968) would support this suggestion; thus a furtheP action of heparin in vivo may be its inhibition of the release mechanism of platelets. This action mat contribute to its effectiveness as an antithrombotio agent and be involved in some curious findings, fơ̂ example, the wave-like bleeding time when hig concentrations of heparin are given (Hjort, Borche grevink, Iverson, and Stormorken, 1960).

This work was carried out during the tenure of a grant from the Wellcome Trust which is gratefully acknow ledged. The platelets were counted by equipment kindlo lent by Tenovus. 


\section{REFERENCES}

Clayton, S., and Cross, M. J. (1963). J. Physiol. (Lond.), 99, 82P. Grette, K. (1962). Acta physiol scand., 56, suppl. 195.

Hjort, P. F., Borchgrevink, C. F., Iverson, O. H., and Stormorken, H. (1960). Thrombos. Diathes. haemorrh. (Stuttg.), 4, 389. Hovig, T. (1963). Ibid., 9, 248.

O’Brien, J. R. (1963). Nature (Lond.), 200, 763. (1968). Lancet, 1, 779.
-, and Heywood, J. B. (1967). J. clin. Path., 20, 56.

_-, and Heady, J. A. (1966). Thrombos. Diathes. haemorrh. (Stuttg.), 16, 752 .

-, and Woodhouse, M. A. (1968). Exp. Biol. Med., 3, 90.

Rowsell, H. C., Glynn, M. F., Mustard, J. F., and Murphy, E. A. (1967). Amer. J. Physiol., 213, 915.

Skoza, L., Zucker, M. B., Jerushalmy, Z., and Grant, R. (1967). Thrombos. Diathes. haemorrh (Stuttg.), 16, 752.

Spaet, T. H., and Zucker, M. B. (1964). Amer. J. Physiol., 213, 1267. 